\title{
Collecting rich qualitative data on business relationships and networks in CEE countries: Challenges and plausible solutions
}

\begin{abstract}
Collecting rich qualitative data in business-to-business market context, where respondents are more reluctant towards investing time in academic research, may impose several barriers for researchers. In particular, challenges may emerge in collecting data and establishing its trustworthiness in Central Eastern European (CEE) countries, due to a distinct business context that has developed over several historical instances.
\end{abstract}

The aim of this paper is to investigate and understand the methodological challenges of collecting rich qualitative data on business relationships and networking in CEE countries. The countries in focus are Russia, Croatia and Hungary. In order to achieve our aims, we critically reflect on personal experiences and consult the literature on conducting research in the aforementioned countries. The contribution of the paper lies in implications for methodological specifics and plausible solutions to overcome barriers to conducting qualitative research on business relationships and networks in CEE countries.

Keywords: methods; business networks; business relationships; qualitative; interviews; Central Eastern European countries. 


\section{Introduction}

Studies on business-to-business (B2B) marketing and knowledge of business relationships and networks have advanced rapidly since the IMP Group was formed in the 1970s (cf. Möller \& Halinen, 2000). Traditional models and theories of business marketing have been changed and adapted to a new economic order, in which networks of connected business actors are playing the pivotal role (Halinen \& Törnroos, 2005). Furthermore, since the establishment of the IMP Group, rapid globalization has led Western businesses to seek new opportunities and establish their position in new markets. This has motivated companies from developed Western countries to engage more proactively in business relationships with companies from emerging markets, including Central Eastern European (CEE) countries. Business network and relationship phenomena are, thus, inherently international.

Although it has been almost three decades since the communist regime in CEE countries collapsed, the mindset of business people in these countries might still be entrenched in past ideologies and cultural specifics. This can pose barriers both to doing business and conducting research in those countries. Additionally, the focus on business network and relationships may pose yet more challenges for research, due to its complexity (Halinen \& Törnroos, 2005). Although there has been a growing amount of business network research in the context of CEE countries, most of the business network and relationships studies are still conducted from a Western perspective (cf. Lowe, Ellis, \& Purchase, 2008). Thus, while network theory is firmly established in developed markets, and its concepts are familiar to Western-based companies and managers, the same concepts may have different connotations for CEE-based companies and managers, due to the 
different socio-cultural context (cf. Manning \& Cullum-Swan, 1994). Quantitative surveys in emerging CEE countries may, thus, be compromised by a simple misunderstanding of concepts used in questions, and thereby produce largely distorted results. Qualitative methods may therefore provide better results.

Qualitative methods are widely used in Western-based B2B marketing research and IMP Group studies, in particular through the application of interview-based case studies (Halinen \& Törnroos, 2005). Solely in the Industrial Marketing Management (IMM), 105 case studies were published during the period 1971-2006 (Beverland \& Lindgreen, 2010). Furthermore, qualitative research techniques have been particularly recommended for studying emerging markets (including CEE countries), due to their unstructured nature and greater ability to uncover new constructs and provide in-depth understanding of situational and contextual factors (Burgess \& Steenkamp, 2006; Craig \& Douglas, 2001). However, most of the research in CEE markets has been conducted in a quantitative manner (e.g. Martin \& Grbac, 2003; Miocevic \& Crnjak-Karanovic, 2012; Radaev, 2013; Sheresheva \& Kolesnik, 2011)

Semi-structured face-to-face interviews with individual managers form the main tool for data collection in qualitative studies, and are widely used in Western business network research. As managers are the principal subjects of an interview situation, the contextual conditions should be considered when planning research on business networks and relationships. An interview is similar to any other interaction situation, such as interacting with customers or colleagues, and is embedded in the local social context (Alvesson, 2003). Here, we adhere to a localism view, where an interview (including pre-interview interactions) is an act, which often follows certain scripts or 
logic, based on past experiences, and socio-historical and cultural context (ibid.). We deem it necessary to understand the socio-historical context of the country in which an interview with a manager is situated.

This paper is descriptive in nature and aims to understand the challenges of conducting qualitative research on business network and relationships in CEE countries. We focus in particular on three emerging countries, namely Russia, Croatia and Hungary, chosen for their common historical background, especially related to the communist regime, and concurrently several socio-historical differences. Additionally, the authors have adequate experience of conducting business network research in these countries. Motivated by this focus we address the following research questions: 1) How is socio-historical background related to barriers to conducting research in Russia, Croatia and Hungary? 2) How can these barriers be overcome and rich qualitative data obtained from Russian, Croatian and Hungarian firms and businesspeople? In order to achieve the aims we reflect on our research experiences in the focal countries and consult the previous literature. Based on our research experiences, we focus especially on face-to-face, semi-structured, and to some extent narrative interviewing. Thus, an interview guide present during the interviews acted as an initiating trigger for the respondents' storytelling rather than a strict protocol to follow. The story emerged from a dialogue between the respondents and the researchers, minimizing researcher influence.

The paper is structured as follows. First, we introduce the context of the study, providing information on socio-historical peculiarities of the focal countries. Second, we provide a brief discussion on the methodologies applied in the previous business network and relationships research in Russia, Croatia and Hungary. Third, we present a review and critical reflection on the 
challenges a researcher might face when conducting qualitative face-to-face interviews in these countries, and, based on personal experiences, provide plausible solutions to overcome these challenges. We conclude with a summary of the findings, after which we discuss the contributions of the study and implications for further research.

\section{Russia, Croatia and Hungary: Socio-Historical context}

Socialist and communist ideologies still exert a strong influence on the modern economic and business development of post-communist countries. Social norms of behavior, values and beliefs affected by the reality of socialism can still be found in business practices, despite the business environment shifting towards a market orientation during the last two decades (Runst, 2013).

As the key state of the Soviet Union, Russia was guided by the Marxism-Leninism ideology grounded on state ownership and control of the assets and means of production, a centrally-planned economy, and the elimination of private property and competition (Neill \& Collins, 1964). During the Soviet period, Russia exhibited typical characteristics of collectivism, and hostility toward foreigners. Historically, the development of Soviet society has resulted in the formation of specific values or norms of behavior, such as being reticent in public, giving more credence to word-ofmouth than the official state-owned media, not relying on the rule of law, appreciating corruption and power hierarchy (Rozov, 2011). Another distinctive feature was lagging industrial development; large manufacturing organizations had to source and manage all goods inputs internally, complementary parts had to be produced in one place and there were no buyer-seller relationships typical to a competitive market. An industrial network under bureaucratic control and 
a lack of cooperation incentives from the state frequently resulted in illegal social network formations based on nepotism and interpersonal cooperation for various benefits (Nieminen, 1999). Providing favors and interpersonal loyalty had more influence on business processes than official arrangements (Lewis, 2006).

As a consequence of the socio-historical background, the Russian "post-soviet personality" has a low degree of trust in outsiders (Mattsson \& Salmi, 2013), is suspicious of everything new, respectful of social hierarchy, distrusts institutions, idealizes past achievements of the state, and fosters "blat" (Rozov, 2011). Conventionally, "blat" may be explained as favor via personal relationships (Johanson J. \& Johanson M., 1999). This network of social connections was developed during Soviet times as a response to the shortage of goods and services. Along with privileged access to products, "blat" opened doors to prestige universities, jobs and promotion. It is based on the exchange of favors between closely related people such as family members, friends and neighbors, rather than on monetary relations. The essential elements of the social network include resource exchange, strong personal relationships, and interpersonal trust (Jansson, Johanson, \& Ramström, 2007).

Croatia experienced 45 years of Communist party rule, which left a certain imprint on the leadership and business management style. Historically, compared to other communist nations, Croatian politics and culture were influenced by catholic religion and Austrian influence. Croatians consider themselves closer to Western culture and values. Although Soviet Russia and Croatia (as a part of the former Republic of Yugoslavia) shared ideas of communism, their ways of development toward "the brighter future" had diverged by 1948, the latter looking towards a more 
liberal approach to the country's governance. (Holmes, 1997)

Croatia was similar to the Soviet states in its pathway towards industrialization. However, Croatia adopted a specific approach to socialism, i.e. a self-management system of industrial relations aimed at the decentralization of decision-making processes in industries (Zupanov \& Adizes, 1981). This system replaced the Soviet style centrally-planned regime at the beginning of the 1950s. Self-management pursues the relative decentralization of industrial relations and fortifies the free market forces of labor and manufacturing, while following general governmental guidelines. Additionally, this system supposes that managers and workers are subject to no hierarchical differences and are equal in rights and benefits. Moreover, managerial staff are elected by the workers. Organizational management is executed based on collective participation and cooperation, which has democratic principles. The managerial decision-making process was more oriented to solving problems than bargaining. It was exactly this approach to self-regulation that resulted in Croatians being initially skilled in entrepreneurship and highly competitive. However, similarly to Russia (Shirokova \& McDougall-Covin, 2012; Weck \& Ivanova, 2013), such aspects as trust and personal networking are still crucial to business relationships development in Croatia (Zabkar \& Makovec Brencic, 2004).

The Hungarian socio-historical context is at the same time similar to and different from that of Russia and Croatia. Similarity is seen in its pathway following the Second World War, as it was under a communist regime until 1989, after which came a hard period of transition to postcommunist capitalist country. However, there are some differences as well. After its change of regime, Hungary became a member of NATO, and much earlier than Croatia also joined the 
European Union in 2004. Furthermore, the socialist system was a little different in Hungary than in Russia and in Croatia. Market socialism ruled from 1968 to 1989 (Kornai, 1992).

Market socialism was characterized by decentralized planning, and so-called economic regulators provided the framework for the system, as opposed to centralized planning and direct bureaucratic control. Implementation of the principles of market socialism resulted in the development of conventional market buyer-seller relationships, which became a background for relatively autonomous business operations (Szamuely, 2009). Managers of enterprises gained the autonomy to decide how to structure the organization and allocate costs, and how best to serve the market. Additionally, Hungarian enterprises were allowed to trade with foreign suppliers, which resulted in a more open attitude to international business networking after the collapse of the Communist bloc. Consequently, instead of the repressive and military order of the classic, Soviet type system, business conditions in market socialism are characterized by soft pulpous relationships and unclear hierarchical relations. Hierarchical relations in business and politics for personal benefit remained quite common throughout the communist period in Hungary. For instance, party membership provided more opportunities, knowing the "right" people and being embedded in an interpersonal network for individual gain (Róbert \& Bukodi, 2000).

In sum, while classic socialism is a system of direct bureaucratic coordination, market socialism is regulated by indirect bureaucratic coordination (Kornai, 1992). Though this system had some similarities with the market economy, and gave some room for market coordination, the behavior of economic and political actors is significantly different from that in a market system (Mandják \& Simon 2016). Thus, in the context of market socialism, interpersonal ties between large 
companies' top managers and politicians were important for business survival, as well as for the negotiation of certain economic regulations (ibid.)

Despite differences in the application of communist ideology in Russia, Croatia and Hungary, the echo of that ideology is still largely reflected in industrial market relationships within these countries, affected by e.g. a lack of trust and the importance of personal relationships (Bönker, Müller, \& Pickel, 2002). The next section provides a short overview of methods applied in the previous business network studies in Croatia, Russia and Hungary.

\section{Methods in business network and relationships research}

Despite the wide application of qualitative methods and face-to-face interviews by network researchers in Western Europe, scholars focused on research in CEE countries may encounter problems when using qualitative research methods. The explanation could be found in the characteristics of these countries' economies, where fierce market competition is to some extent a consequence of the socio-historical background. Based on this traditional way of doing business, research is also conducted using past methodologies. As Koporčić, Tolušić and Tolušić (2015, p. 527) questioned: "Is it a matter of still being a country in transition, without perfect regulations and fighting with corruption? Or is it a result of following the wrong directions of economic theories and their suggested practices?" Most of the research in CEE countries still follows the old micro- and macro-economic theories based on competition. There is a belief that only quantitative data and numbers can provide correct and unbiased information. As a result, most studies still employ surveys, which can lead to misunderstanding of concepts and to other challenges. 
In order to gain a better overview of the research methods applied in business relationships and network studies in Russia, Croatia and Hungary, we conducted a brief literature review by looking at four leading B2B journals: Industrial Marketing Management, Journal of Business and Industrial Marketing, The IMP Journal, and Business-to-Business Marketing Journal. The search criteria were as follows. First, we searched for articles with the word Russia, Croatia or Hungary in the complete text. Second, we checked whether the study was focused on Russia, Croatia or Hungary by looking through the abstract or glancing through the whole text. We excluded articles based solely on secondary data or the previous literature. Third, we investigated the primary research method (qualitative or quantitative) applied in the studies, by looking at the methods section of the articles. Where the article was qualitative, we also checked to see whether an outsider or insider perspective was applied.

Outsider/insider refers to the emic/etic approaches in social sciences (Morris, Leung, Ames, \& Lickel, 1999). While emic refers to behavior being described from the perspective of cultural insiders, the etic approach denotes behavior described from a perspective external to the culture (Morris et al., 1999). We consider the employment of an emic perspective crucial to understanding the specifics of business networking and relationships in a certain country. As local business networks may feature a number of contextually-based patterns, a network understanding can only really be developed by participating in the network itself (Ellis, Lowe \& Purchase, 2006). Thus, we treat interviews conducted with managers of firms based in Russia, Croatia or Hungary as an emic/insider perspective, while interviews with managers of Western-based firms are considered an etic/outsider perspective. 
Although studies on Russian business networks are most often qualitative (see Appendix 1), more than half (six out of ten) have been conducted either with an outsider perspective (e.g. Degbey \& Pelto, 2013; Karlsen, Silseth, Benito, \& Welch, 2003; Weck \& Ivanova, 2013) or by interviewing western or local managers of the Russian subsidiaries of Western firms (e.g. Lorentz \& Ghauri, 2010; Salmi \& Heikkilä, 2015; Elg, Deligonul, Ghauri, Danis, \& Tarnovskaya, 2012). While interviewing managers of Western firms' Russian subsidiaries may provide the researcher with an insider perspective, the presence of contextual factors such as Western organizational culture or national culture (pertinent to interviewing western expatriate managers) may play a role in respondents' interpretation. Some researchers have however succeeded in obtaining an insider perspective by conducting qualitative research with local Russian firms (e.g. Abrahamsen \& Håkansson, 2015; Butler \& Purchase, 2008; Tsybina \& Rebiazina, 2013; Voldnes, Grønhaug, \& Nilssen, 2012). In most of these studies, access to the firms was gained through common connections, for example a Russian university (Butler \& Purchase, 2008), or a Western-based company participating in the study (Abrahamsen \& Håkansson, 2015; Voldnes et al., 2012). While qualitative studies on business networks and relationships in Russia have predominantly been conducted by Western-based researchers, all of the five quantitative studies found in the target journals came from Russian-based researchers (e.g. Bek M., Bek N., Sheresheva, \& Johnston, 2013; Radaev, 2013; Smirnova, Naudé, Henneberg, Mouzas, \& Kouchtch, 2011; Sheresheva \& Kolesnik, 2011; Smirnova, Henneberg, Ashnai, Naudé, \& Mouzas, 2011). Therefore, it can be concluded that there is a preference for quantitative type studies among Russian-based researchers, while conducting a qualitative study is still predominantly a Western tradition. 
Studies in the Croatian market are almost solely focused on quantitative methods, using questionnaires and surveys to examine single or dyadic relationships (e.g. Miocevic \& CrnjakKaranovic 2012; Martin \& Grbac, 2003). The existence of only limited research on business networks in Croatia and other former Yugoslavian countries may be due to the nonexistence of business networks as a theoretical concept. In defining networks, these countries are influenced by their own specific socio-cultural contexts (Czernek \& Czakon, 2016; Michailova \& Worm, 2003), and therefore may not be in line with Western definitions. Clear network structures and qualitative research traditions are harder to find or implement in Croatia.

Although in Hungary, as in Russia and Croatia, the mainstream research approach concerning business relationships and networks is quantitative (e.g. Chikán, Czakó, \& Zoltay-Paprika, 2002; Tátrai, 2012), our literature review turned up four qualitative studies. They focus on issues such as success factors in business relationships (Bodi-Schubert, 2014), the foundation of business relationships (Mandják, Szalkai, Neumann-Bódi, Magyar, \& Simon, 2015, 2016), or strategizing (Mandják, Szalkai, Neumann-Bódi, Magyar, \& Simon, 2014). All four studies were conducted by Hungarian-based researchers and have an insider perspective (i.e. through interviewing Hungarian managers). Thus, we can conclude that the practice of qualitative business research is better established in Hungary than in Croatia and Russia. The qualitative nature of research activities on business relationships and networks in Hungary is partly the consequence of differences in sociohistorical context, namely its period of market socialism (Kornai, 1992). During that era, economist scholars were interested in and investigated the behavioral patterns of business relationships and connectedness of economic actors (Lavigne, 1997), which may be to some extent assimilated into today's business relationships and networks. Their work was mainly based on 
large and deep case studies (Berend 2014). However, it should be noted that the four studies we found in our literature review were either 1) a single company study based on an extensive amount of primary and secondary data (i.e. the same case company was used in Mandják et al., 2014, 2015, 2016), or 2) based on interviews within a focal company and two of its partner companies (BodiSchubert 2014). Thus, it can be concluded that the Hungarian context may still present some barriers to qualitative data collection.

Finally, it is important to note that CEE countries cannot simply borrow and implement already developed Western theories and methods. Nevertheless, academics can benefit from expanding existing theories and modifying methods of data enquiry. Due to their flexible and explorative nature, qualitative methods are found to be more relevant for these purposes and may provide more thick and rich data (Eisenhardt, 1989; Yin, 2003). Following this line of reasoning, it is important to highlight that "An appropriately balanced integration of Western theories and data generated in the CEE context might enable academics to build a 'theoretical two-way bridge' between the West and CEE. Such a theoretical bridge would not only aid in understanding the organizational and managerial transition in CEE but would also deepen the comprehension of organizational and managerial change in highly turbulent environments in general" (Michailova \& Liuhto, 2001, p. 13).

In the next section, we reflect on the qualitative interview methodology. We adopt an CEE perspective on the process of conducting interviews by reflecting on personal experience of researching business relationships and networks in Russia, Croatia and Hungary. 


\section{Challenges of collecting interview data in CEE countries}

An interview is a "socially and linguistically complex situation" (Alvesson, 2011, p. 4) that requires: 1) scrupulous preparation before it, 2) scrutiny during the interview itself, and 3) a reflexive approach to its analysis. In the following subsections we describe the challenges related to the aforementioned phases of a face-to-face, semi-structured interview process. In doing so, we reflect on our experience of conducting interviews on the topic of business networks and relationships in Russia, Croatia and Hungary.

\subsection{Preparations for the interview}

The preparations for the interview include, amongst other practices, constructing the interview guide, approaching the respondents, and setting the interview date and place.

Constructing questions and asking them is an art in itself, especially when that concerns the business network field and theory, which is not yet internationally widespread. Business network theory (Håkansson \& Snehota 1995, Håkansson, Ford, Gadde, Snehota, \& Waluszewski, 2009) is largely embedded in Western European tradition (Ellis et al., 2006). Thus, the researcher should be aware of the potential misunderstandings that might occur during an interview when using concepts such as business networks, relationships, trust and commitment. From a linguistic, semiotic perspective, the meaning of a concept may vary depending on the interpretant or the context (see Manning \& Cullum-Swan, 1994). In Russia, the concept "business network" may be understood as a supply chain or retail chain, due to the numerous linguistic connotations of the 
word "network" and the predominance of dyadic forms of relationship in Russian markets (Torkkeli \& Ivanova, 2013). Similarly to Russia, Hungarian managers may misunderstand "network" due to its variety of connotations, linked to multi-level marketing, or imbue political character to the word. However, generally speaking, there is a sufficient understanding of the business network concept in Hungary, and asking about a company's business network rarely creates misunderstandings. In Croatia, due to managers' perception of markets simply as platforms for competition, the business network concept is almost non-existent (Koporčić et al., 2015). Other factors that could lead to a misunderstanding of the concept in Croatia are: no scholarly tradition, politics, no clear economic interest in collaboration, and sometimes even negative connotations to cooperation. Therefore, when developing an interview guide for a study on business relationships and networks in CEE countries, the researcher should consult the literature or experienced fellow researchers on the possible meanings of network theory concepts in the focal countries. Were the study to be a cross-cultural comparison of understandings of network theory concepts, these types of misunderstanding might actually be beneficial.

Access and entry is one of the most crucial steps in qualitative research (Janesick, 1994). Gaining access to the interview subject may present several challenges, especially in a business network context. Business actors may be more reluctant to be interviewed, due to confidentiality issues, or a lack of time and/or interest. Obtaining access to Russian managers is challenging due to the restricted openness of Russian business leaders and general lack of cooperation between business and academia (see Michailova \& Liuhto, 2001). Therefore, one way to reach Russian managers is through common connections in Russia or through Western partners of Russian firms (see e.g. Butler \& Purchase, 2008; Abrahamsen \& Håkansson, 2015). This kind of approach may in itself 
be culturally nuanced and to some extent resembles the Russian concept of "blat". Among other things, "blat" relates to "favor of access", where access to information or services is gained through a common contact person or a friend (see Ledeneva, 2009).

Interview access in Croatian companies is quite similar to that in Russia. Even though there is no specific cultural concept related to it (such as "blat"), access in most cases will be granted only through a common contact person. Trust and personal connections play the crucial role. The lack of cooperation between academia and practice in Croatia could be a consequence of traditions in academia, where "field research" is mostly done at business-to-consumer (B2C) level. This results in non-existence of e.g. empirical case studies or other qualitative research forms in the B2B field.

Similarly to Croatia and Russia, personal connections and relationships with managers are key to access to companies in Hungary. Previous personal relationships not only build trust and better understanding between academia and business, but typically enable the establishment of "researchbased" relationships. These can furthermore help in deepening the research and obtaining access to other managers within the focal company, and sometimes also to other companies. Another factor that may enable access to qualitative data in Hungary is the size of the company and its organizational culture. While large companies have a more open-minded culture and are easier to access, owners and managers of small and medium-sized companies (SMEs) may exhibit less communicative behavior. For instance, during research on the role of trust (Piricz, 2010), some of the managers did not want to supply any information about their most important business relationship, which they considered strictly confidential. 
Once access is granted and the interview date and time set, the researcher should still send a reminder to a Russian manager. This is due to a different perception of time in Russian culture, i.e. short-term orientation (see Jansson et al., 2007). Most of the Russian respondents asked us to call a few days before the agreed interview date to confirm the exact time of the interview. In Croatia, after the interview was confirmed through a common contact person, the researcher still needs to call the respondent to make personal contact, and set up a date, time and location. After that, an official email with preliminary interview questions should be sent, as well as a reminder of the interview details. However, there was no need to confirm the interview details a few days in advance. Thereby, the pre-interview routine in Croatia is similar to that of Western countries, and neither was a reminder required in Hungary after the date and time are set.

\subsection{Interaction during the interview}

An interview qualifies in itself as an interaction event, and therefore the blending of the participants' social characteristics could affect the outcome (Polsa, 2007). Factors such as gender, education, and cultural background could have an impact (ibid.).

The B2B context of CEE markets may be highly dominated by male managers, so the interviews may mostly represent male-male or male-female encounters. As some researchers point out, in an interview setting a man commonly seeks to show and preserve his masculinity and be in control of the situation (Schwalbe \& Wolkomir, 2003). Thereby, the interviewer should "allow men to feel in control and powerful in a particular way: by providing useful information" (ibid., p. 60), i.e. give them the feeling of being 'experts' in their field. According to Schwalbe and Wolkomir 
(2003), the feeling of being in control may increase male respondents' openness and articulation of their thoughts and actions.

Both in Russian and Croatian culture, men still occupy the main managerial positions in companies. Voldnes, Grønhaug and Sogn-Grundvåg (2014) state that due to Russian men being sexist, a young female researcher may encounter challenges in obtaining the necessary information and being taken seriously. Voldnes et al. (2014), however, base this assumption on their own experiences of being in an interview setting with a Russian male manager and a male research colleague. In this setting, the male fellow researcher was perceived as more authoritative (ibid.). Our experience, however, produced contrasting results. Both in Russia and Croatia, the interview encounters were strictly female-male, and most of the male managers acted openly, almost "lecturing" the young female researcher. While this "lecturing" may be perceived as sexist, the male managers felt in control of the situation and, thus, may have been more open and expressive. When answering questions during the interview, they would often give practical examples to justify and explain their behavior and certain actions. More narrative stories could, thus, be gathered and better insight gained into particular problems.

Qualitative studies on business networks and relationships often require thorough description in order to reveal the complexities of the studied phenomena (Halinen \& Törnroos, 2005). Recording an interview provides a better opportunity to grasp all the details of the case. However, as Michailova and Liuhto (2001) state, the risk of being refused the opportunity to tape-record the interview in CEE countries is extremely high. Contrary to Michailova and Liuhto (2001), the researchers did not encounter any obstacles to getting permission to record the interviews in 
Russia, Croatia or Hungary. This may, however, be related to the nature of the research and questions, or due to having established access through connections. In our cases, questions were largely focused on telling the stories of respondents' previous and current business relationships, mostly based on their personal experiences (see Halinen \& Törnroos, 2005). Thus, the respondents were not required to reveal secret financial information or data that might be beyond their scope of responsibility.

Furthermore, small talk and sharing personal information at the beginning of the interview was generally found to be useful. "Small talk enacts social cohesiveness, reduces inherent threat values of social contact, and helps to structure social interaction" (Coupland, 2003, p. 1). Besides formal small talk and asking questions about the respondents' professional background (such as "How did you start with this company? What is your current role?"), respondents in Croatia, Russia and Hungary were willing to share more detailed stories, going deeper into their personal background. Furthermore, they were interested not only in the context and aims of the research, but also in the researcher's background. In Croatia and Hungary, "ice breaking” often started with exchanges of personal stories about how the researcher and respondent knew their contact person or mutual acquaintances, whereas in Russia the researcher was often asked about her personal background. Furthermore, in Hungary, referring to the manager's professional success, exchanging bon mot, or making insightful remarks, also helped to establish a good atmosphere at the interview. Such initial interpersonal interactions helped establish rapport and raised initial trust from the respondents. The more personal information was shared, the more the respondents seemed to relax and be approachable, and the researchers had the chance to access richer and more "real-life" information. 


\subsection{Establishing credibility of the interview data}

There is a growing call in the field of $\mathrm{B} 2 \mathrm{~B}$ marketing to provide more research details in order to increase the value of qualitative data presented in studies (Beverland \& Lindgreen, 2010). In applying qualitative interview methodology, the researcher should verify the interview findings and establish their trustworthiness (Kvale, 1996). Various criteria have been developed to govern qualitative data trustworthiness (see Elliot, Fischer, \& Rennie, 1999). However, they represent a Western perspective, and as Lincoln and Guba (1985) state, the criteria should be adapted in accordance with the particular research paradigm, focus and context. In the following section we reflect on the Lincoln and Guba (1986) criteria for trustworthiness in applying them to the CEE countries' context. We review the criteria for qualitative research credibility (i.e. prolonged engagement, peer debriefing, triangulation, member checks), identify issues that need to be resolved in order to enhance the quality of research conducted in these countries, and present suggestions based on our own research experience.

First, prolonged engagement is often required in qualitative research to gain a prior understanding that enables better results in terms of interviewing and proper interpretation of the data (cf. Gummesson, 2003). In most cases, B2B research does not allow for prolonged engagement, due to time constraints on the studied subjects. The CEE country context makes prolonged engagement even more complicated, due to managers' lack of trust, and restricted access to data. However, one way to secure at least a degree of prolonged engagement is for the researcher to share a common cultural background with the respondent, and/or be conversant with the business context in the studied country. Thus, in our case, no prolonged engagement as such was needed, since the authors 
are originally from the focal countries and have extensive knowledge of the business context there.

Second, peer debriefing should be conducted by presenting the research results to a neutral peer for constructive feedback. While the applicability of this factor may not be context dependent, care should be exercised in selecting the venue at which to present the research. In order to ensure the credibility of the findings from an insider, emic perspective, the presence of researchers with the same cultural background or knowledge of the CEE business context would be constructive. The number of researchers from CEE countries to be found at Industrial Marketing and Purchasing group (IMP) conferences is usually low, but visiting conferences in countries of interest, or those focused on emerging markets (e.g. IMP Asia) could be effective. Presenting research to professional communities, e.g. chambers of commerce, would also be beneficial. While contacting local chambers of commerce might present some challenges due to institutional barriers, presenting the findings at Western countries' chambers of commerce oriented to promoting trade with CEE countries might be an alternative.

Third, a qualitative researcher should accomplish the best possible triangulation of data, which implies amongst other factors, various sources of data collection. Russian companies willingly provide information on their products and services, often perceiving the interview as a form of "sales encounter". However, obtaining more specific secondary data on the company may be almost impossible (Voldnes et al., 2014). To the authors' knowledge, a similar reluctance to provide information may be encountered when approaching official bodies such as chambers of commerce. The authors have observed first-hand that Croatian companies also are reluctant to provide valuable data, e.g. numeric, due to the fear of information leakage in a competitive 
marketplace. In Hungary, company size plays the decisive role when attempting to gather secondary information. Thus, large companies are open to providing specific secondary data while SMEs may exhibit a certain degree of reluctance.

There is also limited potential for obtaining company information on the Internet (cf. Voldnes et al., 2014). This concerns both basic information such as employee contact details, and more specific numeric data e.g. turnover. For instance, while most Finnish companies provide contact details for staff in specific positions, Russian companies often provide only a switchboard number and rarely disclose information on persons in charge of specific business areas or departments. Such a seemingly insignificant limitation may well slow the research process.

Finally, credibility is also enhanced through member checks, which include verifying data by providing the respondents with study findings in order to validate data interpretation (Lincoln \& Guba, 1985; Silverman, 2011). While providing companies with research reports and verifying the findings is common practice in Western countries, Russian and Croatian managers are in the authors' experience mostly not interested in obtaining this type of information. Michailova and Liuhto (2001) argue that first, Russian managers are not interested in an "outsider" perspective on their business operations and, second, they lack experience of interaction with academia. The authors have seen no dramatic change in the situation during the past 15 years, and only one manager was interested in obtaining further information on the research, specifically in the form of published articles, which might be due to his academic background. In the Croatian managers' case, the researcher perceived that the value of information from research reports was not appreciated, which can also be interpreted as a lack of experience on the managers' part of 
collaboration with academia. It might further be the case that the managers are unaware of the reputational benefits to be gained, especially for small and medium sized (SME) companies. Finally, in Hungary, this factor was also dependent on company size. While managers from large companies were genuinely interested in the results of the research, the interest of SME managers depended very much on their personality and open mindedness.

In sum, scholars conducting research in CEE countries might not be able to fully satisfy some of the criteria for establishing the credibility of qualitative data and, thus, should seek novel solutions to this problem.

\section{Discussions}

This study set out to understand the challenges of conducting qualitative business network research in CEE countries, and answer two research questions: 1) How is socio-historical background related to barriers to conducting research in Russia, Croatia and Hungary? 2) How can these barriers be overcome and rich qualitative data obtained from Russian, Croatian and Hungarian firms and businesspeople? Next, we elaborate on these two questions.

\subsection{Socio-historical embeddedness of research challenges}

The different socio-historical background of each of the studied CEE countries clearly influences managers' behavior and their readiness to participate in academic qualitative research. More precisely, imprints of socialist and communist ideology (Kornai 1992, Holmes, 1997, Runst, 2013) 
and behavior patterns, such as 'blat' in Russia (Butler \& Purchase 2008, Ledeneva, 2009), may make qualitative data collection more complicated (see Table 1). Thus, the high importance of interpersonal connections, consequent upon the traditions of blat and low trust in outsiders in Russia, the highly competitive market landscape in Croatia, and hierarchical relationships in business in Hungary, all impact access to companies and the overall data collection process.

Another core challenge, rooted in socio-historical context, is the respondents' understanding of business network phenomena in the focal countries. The formerly state-controlled economy in Russia and self-management system in Croatia may still be largely reflected in managers' understanding of business networks. While in Russia, networks are perceived to some extent in a hierarchical manner, and are compared to supply or retail chains, competitive traditions in Croatia result in a lack of knowledge on the business network concept per se. Additionally, given that the findings concerning the lack of cooperation between business and academia in Russia correspond with Michailova and Liuhto (2001), we can draw the conclusion that there has been no dramatic change in the country concerning the importance of academic research to business. We have also found that similar conditions prevail in Croatia. Hungary appears to have reached a different maturity level concerning managerial knowledge on the concept of business networks, which may be due to its background in market socialism and research traditions of investigating the connectedness of economic actors (Lavigne, 1997).

Despite the countries' different socialist regimes, our study shows that the research barriers in Croatia, Hungary and Russia are quite similar. In the following section we present some plausible solutions for researchers on how to overcome the potential barriers to obtaining qualitative data in 
the focal countries.

\subsection{Plausible solutions to obtain rich qualitative data in CEE countries}

Our results provide two main threads on how to overcome the barriers to obtaining rich qualitative data from Russian, Croatian and Hungarian businesspeople. The first is to adopt an adequate approach to qualitative research, based on the socio-historical background of the focal countries. The second is to adapt the qualitative research process (Lincoln \& Guba 1985), i.e. preparation for interview, interaction during interview, credibility of interview data, to the specific context of these countries.

The main issues pertaining to adapting the qualitative research process in Russia, Croatia and Hungary are summarized in Table 1 . The adaptation is necessary to overcome the barriers to obtaining rich qualitative data. Table 1 provides some plausible solutions to overcome the challenges a researcher may face during each phase of the research process. 
Table 1. Summary of the research challenges and solutions

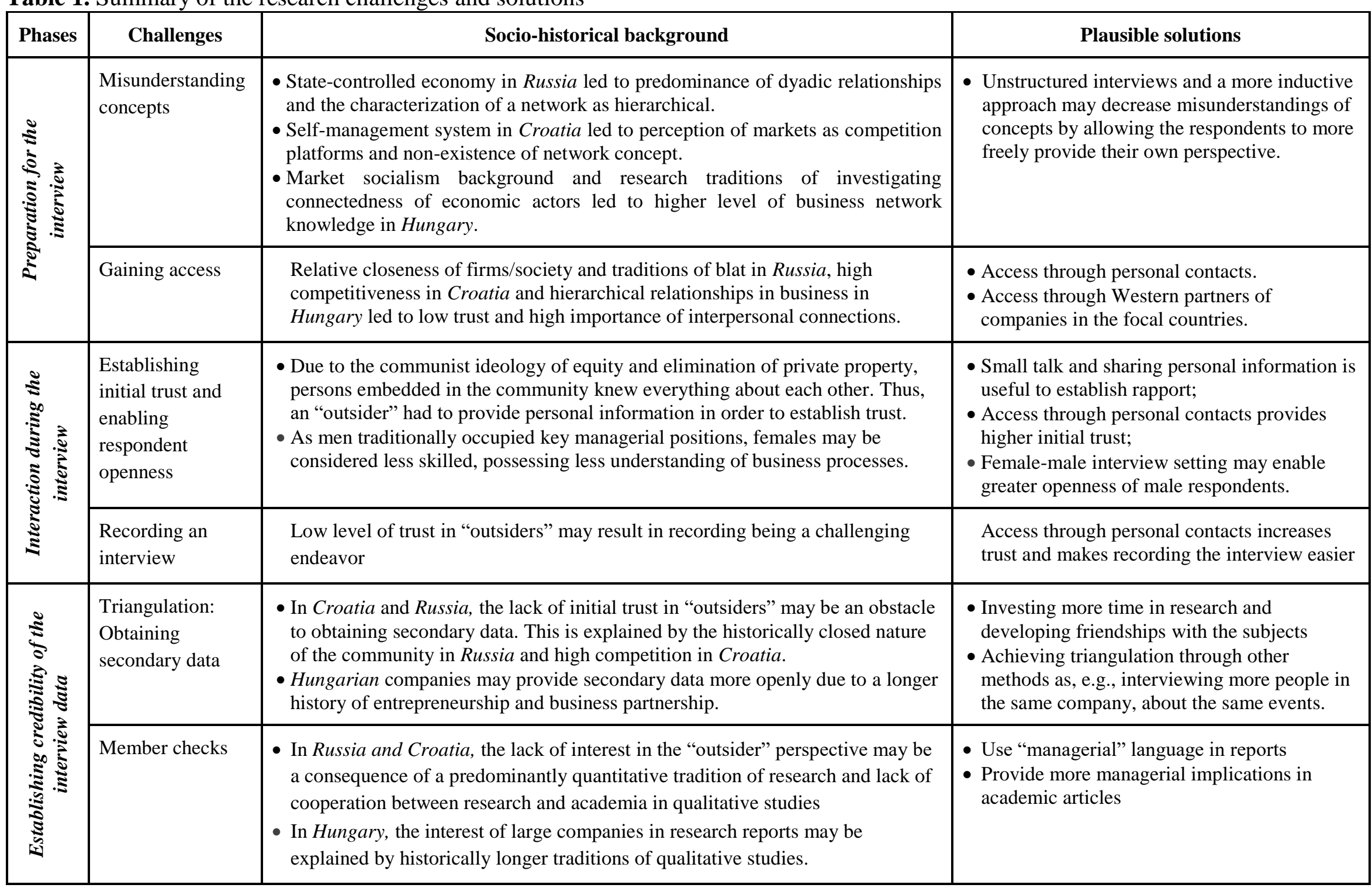


Our findings show that acquiring a common contact person during interview preparation seems to be one of the core solutions to gather rich information from respondents in CEE countries, overcoming most of the research barriers. A common contact person facilitates access and may enable initial trust. While Feldman, Bell and Berger (2003) describe the process of gaining access as relationship building, we see the process in CEE countries as a network expansion based on the extant relationships. The common contact person may be acquired either through the researcher's personal networks, and be e.g. a close friend or acquaintance, or by asking Western managers participating in the study to assist the researcher in establishing connections with their partners in Russia, Hungary or Croatia. Thus, personal relationships and connections seem to be crucial not only in the business context within the focal countries (Jansson et al., 2007; Ivanova \& Torkkeli, 2013), but also for conducting research in business settings.

Other solutions to obtain richer interview data on business networks and relationships include interpersonal small talk at the beginning of the interview and conducting the interview in a femalemale setting. These solutions also stem from the socio-historical context, in particular from historically low trust in outsiders and the need to exchange personal information to gain trust (Mattsson \& Salmi, 2013; Zabkar \& Makovec Brencic, 2004), and from the male dominance in industries (Voldnes et al., 2014). As a consequence of male dominance, the still predominant perception of women as less powerful and authoritative (Voldnes et al., 2014), and with the sole role of empathic listener (Pini, 2005), deviate from the Western European standards of gender equality and may be seen as unfavorable by some female researchers (see Pini, 2005). However, we see it as beneficial to business network research and recommend female researchers use their gender as a strength to obtain richer research data, rather than a weakness. 
Another core problem in conducting business network research in Russia, Croatia and Hungary is the respondents' potential misunderstanding of network concepts, due to the lower level of network concepts inception in these countries' business theory and practice. Thus, we advise researchers to adopt a more flexible, inductive approach towards research in CEE countries with, for example, the application of more open-ended, unstructured interviews, and grounded theory (Strauss \& Corbin, 1997). This would enable new, contextually-specific theoretical perspectives to be uncovered and invigorate B2B market theory (Sheth, 2011).

Once the interview data have been obtained, the main difficulty relating to validating qualitative interview data in Russia, Hungary and Croatia resides in the problems of applying criteria of credibility (Lincoln and Guba, 1985). We propose some solutions to reaching credible research results in the focal countries, as follows: First, due to the complexities of accessing secondary data (see section 4.3 and Table 1), investing more time in and developing a closer personal relationship with the respondent may ease the path to obtaining sensitive secondary information, such as financial data. Failing that, other methods of triangulation (Lincoln \& Guba, 1985) can be used as an alternative to secondary information, for example taking field notes and obtaining more perspectives on the phenomena through snowball interviewing (Biernacki \& Waldorf, 1981) (i.e. through the first contact person).

Second, making B2B research more relevant to CEE practitioners may facilitate member checks. The practical relevance of research is a common problem in the field of B2B marketing (Kuusela, Närvänen, Saarijärvi \& Yrjölä, 2014). In particular, the highly scientific and general character of 
managerial implications (Baraldi, La Rocca \& Perna, 2014) may deter managers from obtaining knowledge from academic articles. In the CEE context, aside from the overall lack of qualitative research practice, the Teutonic intellectual style (Ventola \& Mauranen, 1996) that emphasizes theory formation and generalization over practical, specific implications (see Galtung, 1981) may lead to an even more complex presentation of managerial implications. Therefore, similar to Baraldi et al. (2014), we would recommend researchers in CEE countries apply less scientific language when writing up managerial implications and reports for managers. This may increase the practical relevance of research in those countries and, thus, increase the research participants' interest in member checks.

\section{Conclusions}

Western countries have rapidly developed their theory and research, producing an established qualitative tradition in obtaining case study data. Qualitative study is fundamentally exploratory in nature (Seidman, 1998) and takes a careful interest in sociocultural and personal, individual experiences, allowing the representation of context and meaning in participant experiences. Interviews are especially beneficial when motivated to provide "thick descriptions" (Woodside and Wilson, 2003), where the main objective is to achieve a deeper understanding of participant paths and decisions. In the IMP research stream, qualitative methods are widely used in interviewbased case studies (Halinen \& Törnroos, 2005), as they provide a deep understanding of situational and contextual factors of business relationship and networks (Craig \& Douglas, 2001).

Yet, emerging countries, such as the CEE, are persisting with traditional micro- and 
macroeconomic theories and quantitative data. We have sought to overcome this gap by studying the specific conditions of obtaining rich qualitative data in three CEE countries. We highlight in particular the "insider" perspective that focuses on gathering data that emanate from locally-based firms and managers. In doing so, we point to the importance of collecting data that enable an understanding of contextually-based patterns in the networks, which may only be obtained from the local business network insiders (see also Ellis et al., 2006).

In sum, a different historical pathway, the semantic differences attached to the word "network", and an atmosphere of less cooperative and trusting business practices make the context of CEE countries different to that of the Western countries. As our results show, this different sociocultural context demands a different method of qualitative data collection. It needs an adapted, socially and culturally adequate approach to data collection, as well as careful data interpretation.

\subsection{Theoretical contributions and implications for researchers}

This study makes several contributions to the field of business marketing. The main contribution is to the scarce business marketing literature on methodologies and ways of conducting research (Halinen \& Törnroos, 2005; Lowe \& Hwang, 2012). Our research especially provides contributions to the emerging interpretative method literature in the business marketing setting. The interpretive methodology might be one of the pillars that help bridge the so-called relevance gap between academic theories and managerial practice (Granot, Brashear, \& Motta, 2012). Our research involves characteristics of rich interpretative data collection in three CEE countries, 
which fits the line of inquiry following the basic assumption "that the meaning people make of their experience affects the way they carry out that experience" (Granot et al., 2012, p. 549).

We contribute in particular to the qualitative methodology research by emphasizing the role of a female-male setting to obtain rich interview data. The previous research highlights the importance of the researcher's qualifications, such as age and gender, in relation to national culture differences (Polsa, 2007). Contrary to the previous research (Voldnes et al., 2014, Polsa, 2007), the main implication of the current study is that due to the male domination of management positions in heavy industry in Russia, Croatia and Hungary, the female-male setting of the interview can benefit business network research in those countries.

The research also contributes to the business network literature by highlighting the equally important role of personal relationships and connections in business networking, not only in the Russian context (see Mattsson \& Salmi, 2013) but also in other post-Soviet countries, which are currently EU members (i.e. Croatia and Hungary). Furthermore, the study adds to the scarce business network research on CEE countries (Tretyak, 2013). The research also adds to the previous literature by emphasizing the need to enhance the practical relevance of $\mathrm{B} 2 \mathrm{~B}$ marketing research (e.g. Baraldi et al., 2014) specifically in CEE countries, and promote such research as credible and necessary for companies and society in this context.

In sum, we agree with Sheth (2011, p. 180) that "research on emerging markets [including those of CEE countries] is not just a "nice thing to do"; it is increasingly becoming a necessity" in both B2B and B2C marketing, since it provides innumerable opportunities for theory development. This 
includes developing and adapting network theories based on insights from CEE countries. The previous studies, however, indicate the challenging nature of conducting research in CEE countries (Mattson \& Salmi, 2013; Michailova \& Liuhto, 2001). Thus, the main practical implication of the current study lies in providing several recommendations and plausible solutions for business marketing researchers on how to overcome the possible challenges and obtain rich qualitative data from Russian, Croatian and Hungarian businesspeople. We also assume that the solutions outlined may be applicable in other CEE countries. Researchers should apply these solutions by carefully weighting them against the specific context of the study.

\subsection{Further research suggestions}

Given the exploratory nature of the research, further conceptual and empirical investigation is required. First, while there is a lack of qualitative research on business networks and relationships in Croatia, this kind of studies in Russia have mainly been conducted by foreign scholars (e.g. Salmi \& Heikkilä, 2015; Voldnes et al., 2012), and in Hungary by a limited group of researchers (e.g. Mandják et al., 2014, 2015, 2016). Thus, the current article calls for more qualitative research on business relationships and networks in CEE countries.

Second, in order to obtain a more comprehensive understanding of the specifics of conducting business network research in CEE countries, experiences from countries other than Russia, Croatia and Hungary are needed. Thus, conducting similar qualitative research in other CEE countries may reveal additional challenges and barriers, depending on the maturity level of knowledge on 
business network theories. Another avenue for future research would be to compare the findings of this study with experiences of conducting research in other emerging countries which are not part of CEE.

Third, the results of this study are largely based on the authors' research experiences in the focal countries. While the findings have been verified by peer debriefing from a relevant academic conference, further research would benefit from additional verifications of the findings with more scholars experienced in business network research in Russia, Croatia and Hungary. This would enable the investigation of additional factors that might have a role in conducting qualitative research on business networks in these countries.

Fourth, the female researchers in the current study are young scholars and, therefore, further research is needed to exclude the role of age in female researchers obtaining data in CEE countries. Additionally, due to the Hungarian researcher being male, we were not able to obtain the Hungarian perspective on the peculiarities of female-male interview settings. Thus, further research is required concerning this matter, too.

Finally, the study investigates solely a qualitative interviewing technique, in particular, face-toface, semi-structured and narrative interviewing. Other qualitative tools, such as open, unstructured interviews, observations and grounded theory approach, should also be carefully weighted for relevance in conducting research in the studied countries. 


\section{References}

Abrahamsen, M.H., \& Håkansson, H. (2015). Caught in the middle: Buying from markets and selling to networks. Industrial Marketing Management, 49, 4-14.

Alvesson, M. (2003). Beyond neopositivists, romantics, and localists: A reflexive approach to interviews in organizational research. The Academy of Management Review, 28(1), 13-33.

Alvesson, M. (2011). Interpreting interviews. London: SAGE.

Baraldi, E., La Rocca, A., Andrea Perna , (2014)," Good for science, but which implications for business? An analysis of the managerial implications in high-impact B2B marketing articles published between 2003 and 2012 ", Journal of Business \& Industrial Marketing, Vol. 29 Iss $7 / 8$ pp. $574-592$ isEp:

Bek, M.A., Bek, N.N., Sheresheva, M.Y., \& Johnston, W.J. (2013). Perspectives of SME innovation clusters development in Russia. Journal of Business \& Industrial Marketing, 28(3), $240-259$

Berend, I. T. (2014). The economic response to globalization, recovery and growth, the integration of Eastern and Western Europe. Society and Economy, 36(1), 5-20.

Beverland, M.B., \& Lindgreen, A. (2010). What makes a good case study? A positivist review of 
qualitative case research published in Industrial Marketing Management, 1971-2006. Industrial Marketing Management, 39(1), 56-63.

Bieranacki, P., \& Waldorf, D. (1981). Snowball sampling: Problems and techniques of chain referral sampling. Sociological Methods \& Social Research, 10, 141-163.

Bodi-Schubert, A. (2014). The conceptual model of success in buyer-supplier relationship. IMP journal, 8(3), 31-43.

Burgess, S.M., \& Steenkamp, J-B. (2006). Marketing renaissance: How research in emerging markets advances marketing science and practice. International Journal of Research in Marketing, 23(4), 337-356

Butler, B., \& Purchase, S. (2008). Use of social capital among Russian managers of a new generation. Industrial Marketing Management, 37(5), 531-538.

Bönker, F., Müller, K., \& Pickel, A. (2002). Cross-Disciplinary Approaches to Postcommunist Transformation: Context and Agenda. In F. Bönker, K. Müller, \& A. Pickel (Eds.), Postcommunist Transformation and the Social Sciences (pp. 1-38). Lanham, MD: Rowman and Littlefield.

Chikán, A., Czakó, E. \& Zoltay-Paprika, Z. (Eds.). (2002). National Competitiveness in Global Economy - The Case of Hungary. Budapest: Akadémiai Kiadó. 
Coupland, J. (2003). Small talk: Social functions. Research on Language and Social Interaction, 36(1), 1-6.

Craig, C.S., \& Douglas, S.P. (2001). Conducting international marketing research in the twentyfirst century. International Marketing Review, 18(1), 80 - 90.

Czernek, K., \& Czakon, W. (2016). Trust-building processes in tourist coopetition: The case of a Polish region. Tourism Management, 52, 380-394.

Degbey, W., \& Pelto, E. (2013). Cross-border M\&A as a trigger for network change in the Russian bakery industry. Journal of Business \& Industrial Marketing, 28(3), 178 - 189.

Eisenhardt, K.M. (1989). Building theories from case study research. Academy of Management Review, 14(4), 532-550.

Elg, U., Deligonul, S.Z., Ghauri, P.N., Danis, W., \& Tarnovskaya, V. (2012). Market-driving strategy implementation through global supplier relationships. Industrial Marketing Management, 41(6), 919-928.

Elliot, R., Fischer, C.T., \& Rennie, D.L. (1999). Evolving guidelines for publication of qualitative research studies in psychology and related fields. British Journal of Clinical Psychology, 38, 215-229. 
Ellis, N., Lowe, S., \& Purchase, S. (2006). Towards a re- interpretation of industrial networks: a discursive view of culture. IMP Journal, 1(2), 20-40.

Feldman, M. S., Bell, J., \& Berger, M.T. (2003). Gaining access: A practical and theoretical guide for qualitative researchers. Walnut Creek, CA: AltaMira.

Galtung, J. (1981). Structure, culture, and intellectual style: An essay comparing saxonic, teutonic, gallic and nipponic approaches. Social Science Information, 20, 817-856.

Granot, E., Brashear, T.G., \& Motta, P.C. (2012). A structural guide to in-depth interviewing in business and industrial marketing research. Journal of Business \& Industrial Marketing. 27(7), $547-553$.

Gummesson, E. (2003). All research is interpretive!. Journal of Business \& Industrial Marketing, 18(6/7), 482 - 492.

Halinen, A., \& Törnroos, J-Å. (2005). Using case methods in the study of contemporary business networks. Journal of Business Research, 58(9), 1285-1297.

Holmes, L. (1997). Post-Communism: an introduction. Oxford: Polity Press.

Håkansson, H., \& Snehota, I. (1995). Developing Relationships in Business Networks. London: 
International Thomson.

Håkansson, H., Ford, D., Gadde, L. E., Snehota, I., \& Waluszewski, A. (2009). Business in networks. Chichester: John Wiley \& Sons.

Janesick, V. (1994). The Dance of Qualitative Research Design: Metaphor, Methodolatry, and Meaning. In N.K. Denzin, \& Y.S. Lincoln (Eds.), Handbook of Qualitative Research (pp. 3555). London: SAGE.

Jansson, H.A., Johanson, M., \& Ramström, J. (2007). Institutions and networks: Business networks in the Chinese, Russian, and West-European institutional contexts. Journal of Industrial Marketing Management, 36(7), 955-967.

Johanson, J., \& Johanson, M. (1999). Networks in Transition. In J- $\AA$. Törnroos, \& J. Nieminen (Eds.), Business entry in Eastern Europe (pp. 60-63). Helsinki: Kikimora Publications.

Karlsen, T., Silseth, P.R., Benito, G.R.G. \& Welch, L.S. (2003). Knowledge, internationalization of the firm, and inward-outward connections. Industrial Marketing Management, 32(5), 385396.

Koporčić, N., Tolušić, Z., \& Tolušić, Z. (2015). Introducing the interaction approach for successful business relationships. Econviews - Review of Contemporary Business, Entrepreneurship and Economic Issues, 28(2), 523-533. 
Kornai, J. (1992). The socialist system: The political economy of communism. Oxford: Oxford University Press

Kuusela, H., Närvänen, E., Saarijärvi, H., \& Yrjölä, M. (2014). Challenges for B2B research relevance: a top executive perspective. Journal of Business \& Industrial Marketing, 29(7/8), $593-600$.

Kvale, S. (1996). Interviews: An introduction to qualitative research writing. Thousand Oaks, CA: SAGE.

Lavigne, M. (1997). The political economy of socialism: What is left?. Europe-Asia Studies, 49(3), 479-486.

Ledeneva, A.V. (2009). From Russia with blat: Can informal networks help modernize Russia?. Social Research, 76(1), 257-288.

Lewis, R.D. (2006). When cultures collide: leading across cultures (3rd ed.). London: Nickolas Brealey International.

Lincoln, Y.S., \& Guba, E.G. (1985). Naturalistic inquiry. Newbury Park, CA: SAGE.

Lincoln, Y.S., \& Guba, E.G. (1986). But is it rigorous? Trustworthiness and authenticity in 
naturalistic inquiry evaluation. In D.D. Williams (Ed.). New directions for program evaluation (Vol. 30, pp. 73-84). San Francisco, CA: Jossey-Bass.

Lorentz, H. \& Ghauri, P.N. (2010). Demand supply network opportunity development processes in emerging markets: Positioning for strategy realization in Russia. Industrial Marketing Management, 39(2), 240-251

Lowe S., Ellis, N., \& Purchase, S. (2008). Rethinking language in IMP research: Networking processes in other words. Scandinavian Journal of Management, 24(4), 295-307.

Lowe, S., \& Hwang, K-S. (2012). A NICE agenda for IMP research. Industrial Marketing Management, 41(4), 706-714.

Mandják, T., Szalkai, Z., Neumann-Bódi, E., Magyar, M., \& Simon, J. (2014). Phoenix in the network: The genesis of a Hungarian industrial company, IMP journal, 8(3), 107-119.

Mandják, T., Szalkai, Z., Neumann-Bódi, E., Magyar, M., \& Simon, J. (2015). Emerging relationships: How are they born?. Industrial Marketing Management, 49, 32-41.

Mandják, T., \& Simon, J. (2016). An old picture ... or is it? Relations between business and political networks in Hungary. The IMP Journal, in press.

Mandják, T., Szalkai, Z., Neumann-Bódi, E., Magyar, M., \& Simon, J. (2016). Trigger issues in 
emerging relationships. Industrial Marketing Management, 58, 137-147

Manning, P.K., \& Cullum-Swan, B. (1994). Narrative, context and semiotic analysis. In N.K. Denzin, \& Y.S. Lincoln (Eds.). Handbook of Qualitative Research (pp. 463-477), London: SAGE.

Martin, J.H. \& Grbac, B. (2003). Using supply chain management to leverage a firm's market orientation. Industrial Marketing Management, 32(1), 25-38.

Mattsson, L-G., \& Salmi, A. (2013). The changing role of personal networks during Russian transformation: challenges for Russian management, Journal of Business \& Industrial Marketing, 28(3), $190-200$.

Michailova, S., \& Liuhto, K. (2001). Organisation and management research in transition economies: Towards improved research methodologies. Journal of East-West Business, 6(3), $7-46$.

Michailova, S., \& Worm, V. (2003). Personal Networking in Russia and China: Blat and Guanxi. European Management Journal, 21(4), 409-537.

Miocevic, D., \& Karanovic, B. (2012). The mediating role of key supplier relationship management practices on supply chain orientation - The organizational buying effectiveness link, Industrial Marketing Management, 41(1), 115-124 
Morris, M.W., Leung, K., Ames, D., \& Lickel, B. (1999). Views from inside and outside: Integrating emic and etic insights about culture and justice judgment. Academy of Management Review, 24(4), 781-796.

Möller, K., \& Halinen, A. (2000). Relationships marketing theory: Its roots and direction. Journal of Marketing Management, 16, 29-54.

Neill, T.P., \& Collins, J. (1964). Communism: Why it is and how it works, New York: Sheed and Ward, New York.

Nieminen, J. (1999). Reformulation of business relationships: the role of networks. In J-Å. Törnroos, \& J. Nieminen (Eds.), Business entry in Eastern Europe (pp. 34-37). Helsinki: Kikimora Publications.

Pini, B. (2005). Interviewing men: Gender and the collection and interpretation of qualitative data. Journal of Sociology, 41(2), 201-216.

Piricz, N. (2010). The role of trust from the aspect of business networks. Proceedings of the $26^{\text {th }}$ IMP conference. Budapest, Hungary.

Polsa, P. (2007). Comparability in cross- cultural qualitative marketing research: Equivalence in personal interviews. Journal of Academy of Marketing Science Review, 11(8), 1-18. 
Radaev, V. (2013). Market power and relational conflicts in Russian retailing. Journal of Business \& Industrial Marketing, 28(3), $167-177$.

Róbert P. \& Bukodi E. (2000) Who are the Entrepreneurs and Where Do They Come From? Transition to Self-employment Before, Under and After Communism in Hungary. International Review of Sociology, 10(1), 147-171.

Rozov N. (2011). Russian mentality: the most constructive concepts and their critiques. Mir Rossii, $2,100-113$.

Runst, P. (2013). Post-Socialist culture and entrepreneurship. American journal of economics and sociology, 72(3), 593-626.

Salmi, A., \& Heikkilä, K. (2015). Managing relationships with public officials - A case of foreign MNCs in Russia. Industrial Marketing Management, 49, 22-31.

Schwalbe, M.L., \& Wolkomir, M. (2003). Interviewing men. In J. Holstein, \& J.F. Gubrium (Eds.), Inside interviewing: New lenses, new concerns (pp. 55-72). Thousand Oaks, CA: SAGE.

Seidman, I. (1998). Interviewing as qualitative research (2nd ed.). New York: Teachers College, Columbia University. 
Sheresheva, M.Y., \& Kolesnik, N.A. (2011). Stochastic perspective of industrial distribution network processes. Industrial Marketing Management, 40(6), 979-987

Sheth, J.N. (2011). Impact of emerging markets on marketing: Rethinking existing perspectives and practices. Journal of Marketing, 75(4), 166-182.

Shirokova G., \& McDougall-Covin, P. (2012). The role of social networks and institutions in the internationalization of Russian entrepreneurial firms: Do they matter?. Journal of International Entrepreneurship, 10(3), pp. 177-199.

Silverman, D. (2011). Interpreting qualitative data (4th ed.). London, UK: SAGE

Smirnova, M., Naudé, P., Henneberg, S.C., Mouzas, S., \& Kouchtch, S. P. (2011). The impact of market orientation on the development of relational capabilities and performance outcomes: The case of Russian industrial firms. Industrial Marketing Management, 40(1), 44-53.

Smirnova, M., Henneberg, S.C., Ashnai, B., Naudé, P., \& Mouzas, S. (2011). Understanding the role of marketing-purchasing collaboration in industrial markets: The case of Russia, Industrial Marketing Management, 40(1), 54-64.

Strauss, A., \& Corbin, J. (1997). Grounded Theory in Practice. Thousand Oaks, CA: Sage.

Szamuely, L. (2009) Two reforms under Mono-Party Political system: The Hungarian NEM in 
the 1960s-70s and the Chinese reform. In S. Ichimura, T. Sato \& W. James (Eds.), Transition from Socialist to Market Economies: Comparison of European and Asian Experiences (pp. 67-70). Palvgrave Macmilln, the UK.

Torkkeli, L. \& Ivanova, M. (2013). Managerial understanding of business networking across cultures: An empirical study of Finnish-Russian business dyads. Proceedings of the $39^{\text {th }}$ EIBA conference. Bremen, Germany.

Tátrai, A. (2012). In Global Competition 1996, 1999, 2004 and 2009 - The documentation of the first four surveys. Budapest: TÁRKI Social Research Inc.

Tretyak, O. (2013). Inter-firm relationships in Russia: responding to new challenges. Journal of Business and Industrial Marketing, 28(3), 163-166.

Tsybina, E., \& Rebiazina, V. (2013) Managing portfolios of interconnected customers: evidence from Russian B2B market. Journal of Business \& Industrial Marketing, 28(3). 229-239.

Ventola, E., \& Mauranen, A. (Eds.). (1996). Academic writing: Intercultural and textual issues. Amsterdam: John Benjamins.

Voldnes, G., Grønhaug, K., \& Nilssen, F. (2012). Satisfaction in buyer-seller relationshipsInfluence of cultural differences. Industrial Marketing Management, 41(7), 1081-1093. 
Voldnes, G., Grønhaug, K., \& Sogn-Grundvåg, G. (2014). Conducting Qualitative Research in Russia: Challenges and Advice. Journal of East-West Business, 20(3), pp. 141-161.

Zabkar, V., \& Makovec Brencic, M. (2004). Values, trust, and commitment in business-tobusiness relationships: A comparison of two former Yugoslav markets. International Marketing Review, 21(2), $202-215$.

Zupanov, J., Adizes, I. (1981). Yugoslavia. In A.A. Blum (Ed.), International handbook of industrial relations: contemporary development and research (pp. 645-671). London: Aldwych press.

Yin, R.K. (2003). Case study research: Design and methods (3rd ed.). Thousand Oaks, CA: SAGE.

Weck, M., \& Ivanova, M. (2013). The importance of cultural adaptation for the trust development within business relationships. Journal of Business and Industrial Marketing, 28(3), 210-220.

Woodside, A. G., \& Wilson, E. J. (2003). Case Study research method for theory building. Journal of Business \& Industrial Marketing, 18(6/7), 493-508. 
Appendix 1. Qualitative and quantitative business network and relationships studies in Russia, Croatia and Hungary

\begin{tabular}{|c|c|c|c|c|}
\hline $\begin{array}{l}\text { Focal } \\
\text { country }\end{array}$ & Authors & Year & Title of the paper & Journal \\
\hline \multicolumn{5}{|c|}{ Qualitative with a CEE (insider) perspective } \\
\hline \multirow{7}{*}{ Russia } & Butler \& Purchase & 2008 & Use of social capital among Russian managers of a new generation & Industrial Marketing Management \\
\hline & Voldnes et al. & 2012 & Satisfaction in buyer-seller relationships-Influence of cultural differences & Industrial Marketing Management \\
\hline & $\begin{array}{l}\text { Tsybina \& } \\
\text { Rebiazina }\end{array}$ & 2013 & $\begin{array}{l}\text { Managing portfolios of interconnected customers: evidence from Russian B2B } \\
\text { market }\end{array}$ & Journal of Business \& Industrial Marketing \\
\hline & $\begin{array}{l}\text { Abrahamsen \& } \\
\text { Håkansson }\end{array}$ & 2015 & Caught in the middle: Buying from markets and selling to networks & Industrial Marketing Management \\
\hline & Lorentz \& Ghauri & 2010 & $\begin{array}{l}\text { Demand supply network opportunity development processes in emerging } \\
\text { markets: Positioning for strategy realization in Russia }\end{array}$ & Industrial Marketing Management \\
\hline & Elg et al. & 2012 & Market-driving strategy implementation through global supplier relationships & Industrial Marketing Management \\
\hline & Salmi \& Heikkilä & 2015 & $\begin{array}{l}\text { Managing relationships with public officials - A case of foreign MNCs in } \\
\text { Russia }\end{array}$ & Industrial Marketing Management \\
\hline \multirow{4}{*}{ Hungary } & Mandják et al. & 2015 & Emerging relationships: How are they born? & Industrial Marketing Management \\
\hline & Mandják et al. & 2016 & Trigger issues in emerging relationships & Industrial Marketing Management \\
\hline & Bodi-Schubert & 2014 & The conceptual model of success in buyer-supplier relationship & IMP journal \\
\hline & Mandják et al. & 2014 & Phoenix in the network: The genesis of a Hungarian industrial company & IMP journal \\
\hline \multicolumn{5}{|c|}{ Qualitative with a Western (outsider) perspective } \\
\hline \multirow[b]{2}{*}{ Russia } & Karlsen et al. & 2003 & Knowledge, internationalization of the firm, and inward-outward connections & Industrial Marketing Management \\
\hline & Degbey \& Pelto & 2013 & $\begin{array}{l}\text { Cross-border M\&A as a trigger for network change in the Russian bakery } \\
\text { industry }\end{array}$ & Journal of Business \& Industrial Marketing \\
\hline
\end{tabular}




\begin{tabular}{|l|l|l|l|l|l|}
\hline \multicolumn{1}{|l|}{} & Weck \& Ivanova & 2013 & \multicolumn{2}{|l|}{$\begin{array}{l}\text { The importance of cultural adaptation for the trust development within business } \\
\text { relationships }\end{array}$} & Journal of Business \& Industrial Marketing \\
\hline \multirow{5}{*}{ Russia } & Smirnova et al & 2011 & $\begin{array}{l}\text { Understanding the role of marketing-purchasing collaboration in industrial } \\
\text { markets: The case of Russia }\end{array}$ & Industrial Marketing Management \\
\cline { 2 - 6 } & $\begin{array}{l}\text { Sheresheva \& } \\
\text { Kolesnik }\end{array}$ & 2011 & Stochastic perspective of industrial distribution network processes & Industrial Marketing Management \\
\cline { 2 - 6 } & $\begin{array}{l}\text { Bek et al. } \\
\text { The impact of market orientation on the development of relational capabilities }\end{array}$ & 2013 & Perspectives of SME innovation clusters development in Russia & Journal of Business \& Industrial Marketing \\
\cline { 2 - 6 } & Radaev, 2013 & 2013 & Market power and relational conflicts in Russian retailing & Journal of Business \& Industrial Marketing \\
\hline \multirow{3}{*}{ Croatia } & Martin \& Grbac & 2003 & Using supply chain management to leverage a firm's market orientation & Industrial Marketing Management \\
\cline { 2 - 6 } & $\begin{array}{l}\text { Miocevic \& } \\
\text { Crnjak-Karanovic }\end{array}$ & 2012 & $\begin{array}{l}\text { The mediating role of key supplier relationship management practices on supply } \\
\text { chain orientation - The organizational buying effectiveness link }\end{array}$ & Industrial Marketing Management \\
\hline
\end{tabular}

